\title{
New Macrocycles derived from \\ 4,5-diamino- and 4,5-dihydroxyacridin-9(10H)-ones
}

\author{
Vanina Santini, Gerard Boyer* and Jean-Pierre Galy \\ UMR 6009, Faculte des Sciences de Saint-Jerome Case 552. \\ Av. Escadrille Normandie Niemen. 13397 Marseille Cedex 20. France.
}

\begin{abstract}
The synthesis of new macrocycles by alkylation and acylation of 4,5-diamino- and 4,5-dihydroxyacridin- $9(10 H)$-ones has been performed Several original macrocycles (dilactames, diamides and dilactones) and crown ethers have been obtained.
\end{abstract}

Acridine derivatives are well known therapeutic agents due to their wide range of pharmacological and biological activities, and many derivatives have been reported in the hiterature. ${ }^{(1)}$ Therefore one mechanism of action proceeds by DNA intercalation of the acridine moiety ${ }^{(2)}$ and we are interested since a few years in the preparation of new polyacridines and macrocycles with increased DNA binding properties. For this reason we have previously described the preparation of mono and bi-bridged acridine dimers. "Moreover tetrameric polyacridines have also been reported recently in the lab. ${ }^{(4)}$

Hence we got involved in the $\mathrm{O}$-acylation and alkylation of amino and hydroxy acridinones in order to prepare bisacridin$(10 H)$-ones linked on position 3 or $4^{(5)}$ and macrocycles linked on position 2,3 and 2,7. In this later case several crown ethers were prepared by alkylation of the corresponding dihydroxy derivatives. ${ }^{(6)}$

Now we are interested in the preparation of new macrocycles bridged at positions 4 and 5 using suitable precursors like the symmetrically substituted diamino and dihydroxy acridinones 5 and 8 .

Our approach towards this synthesis was based on the preparation of the 4,5-diamino- $9(10 H)$-acridinone 5 by reduction of the corresponding 4,5-dinitro- $9(10 H)$-acridinone, obtained by Ullmann condensation between the benzoïc acid 1 and o-nitroaniline 2. This synthesis has been reported in the literature but with low yields, especially in the first step of the condensation ( $20 \%$ yield), ${ }^{(7)}$ following this procedure we changed systematically the reported conditions and obtained a yield of $54 \%$ performing the condensation without solvent, during two hours, with 2-bromo-3-nitro benzoic acid 1 and aniline 2 , and carrying the reaction with $1.3 \%$ of copper powder per mmol of 1 , (entry 9 , Table 1 ) ${ }^{(8)}$ 
Table 1: Condensation reactions of 1 with nitro aniline 2.

(All the reactions were carried out with $4 \mathrm{mmol}$ of 1 ).

\begin{tabular}{|ccccccc|}
\hline Entry & $\begin{array}{c}\mathbf{2} \\
\mathrm{mmol}\end{array}$ & $\begin{array}{c}\mathrm{K}_{2} \mathrm{CO}_{3} \\
\mathrm{mmol}\end{array}$ & $\begin{array}{c}\mathrm{Cu} \\
\% / \mathrm{mmol}\end{array}$ & $\begin{array}{c}\text { Reaction } \\
\text { conditions }\end{array}$ & $\begin{array}{c}\text { Solvant } \\
\text { Yield 3 } \\
(\%)\end{array}$ \\
\hline 1 & 6.3 & 4.7 & 10.0 & $160^{\circ} / 3 \mathrm{~h}$ & 2-ethoxy ethanol & - \\
2 & 5 & 4.7 & 3.3 & $180^{\circ} / 3 \mathrm{~h}$ & pentanol & mixture \\
3 & 7.2 & 8 & 10.7 & $180 \% / 5 \mathrm{~h}$ & DMF & - \\
$4^{*}$ & 7.2 & 5 & 10.0 & $80^{\circ} / 3 \mathrm{~h}$ & ethanol & - \\
5 & 7.2 & 3.8 & 6.7 & $190 \% / 2 \mathrm{~h}$ & - & 24 \\
6 & 7.2 & 5.2 & 10.0 & $180^{\circ} / 2 \mathrm{~h}$ & - & 18 \\
7 & 7.2 & 12 & 2.5 & $190 \% / 2 \mathrm{~h}$ & - & 50 \\
8 & 7.2 & 12 & 2.5 & $190^{\circ} / 3 \mathrm{~h}$ & - & 35 \\
9 & 7.2 & 12 & 4.4 & $190 \% / 2 \mathrm{~h}$ & - & 54 \\
10 & 7.2 & 12 & 4.6 & $190^{\circ} / 2 \mathrm{~h}$ & - & 25 \\
\hline
\end{tabular}

Then, the recovered anthranilic acid 3 was cyclized in polyphosphoric acid under reflux to yield the dinitro acridinone 4 with $91 \%$ yield. ${ }^{(9)}$ Finally, reduction of 5 with $\mathrm{SnCl}_{2}$ led to desired 4,5-diamino-9(10H)-acridinone with $78 \%$ yield (Scheme 1). ${ }^{(10)}$

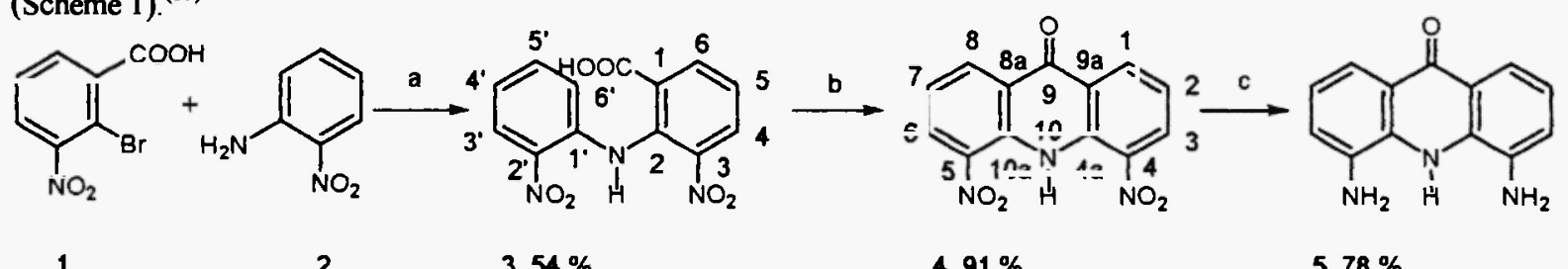

年

$\mathrm{SnCl}_{2}, \mathrm{HCl}, 2 \mathrm{~h}, 100^{\circ} \mathrm{C}$.

The acylation of the 4,5-diamino-9(10H)-acridinone 5 was performed with different alkyl halides containing a variable number of $\left(\mathrm{CH}_{2}\right)$ groups, in pyridine according to a procedure precedently described in our laboratory upon monoamino acridine dimerisation. ${ }^{(5)}$

With suberoyl, ( $n=6$ is the rumber of methylene units in a macrocycle), azeloyl or sebacoyl chlorides $(n=7$ and 8$)$ a mixture of oligomeric mono and diacylated acridinones was obtained with $1: 1$ and $1: 2$ acridinone/acyl chain ratios. These oligomers were separable by crystallization without column chromatography leading to macrocycles 6a-c (18-24 \% yield); e.g. the 4,5-(diamido- $\alpha^{\prime \prime}, \omega^{\prime \prime}$-alkyl)acridin- $9(10 H)$-ones; and to the 4,5-(diamido alcanoic acid)acridin- $9(10 H)$-ones $7 \mathrm{a}-\mathrm{c}(32-35 \%$ yield). (Scheme 2$){ }^{(11)}$ 


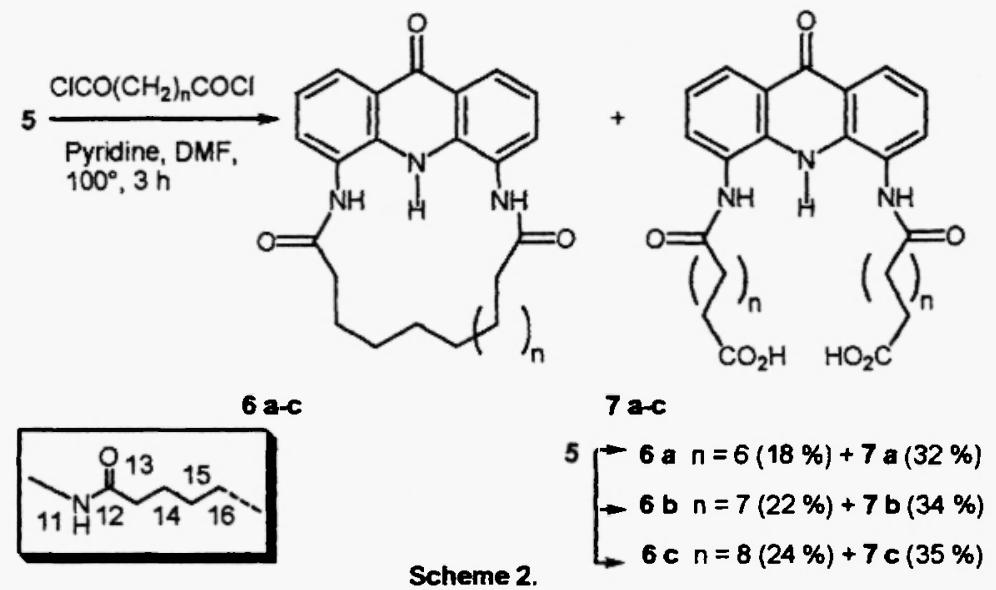

Dihydroxy acridinones are also suitable intermediaries for the preparation of acridono ligand, for this reason we tried also the acylation and alkylation of 4,5-dihydroxy-9(10H)-acridinone 8. The ${ }^{1} \mathrm{H}$ - and ${ }^{13} \mathrm{C}$ NMR spectroscopy of this compound has been described by us, ${ }^{12}$ but its preparation was tedious and not reported until recently by Hungarian scientists. ${ }^{(13)}$ In this latter case only one acridono-18-crown-6 ligand 9 was prepared and reported by $O$-alkylation of the 4,5-dihydroxy-9(10H)-acridinone using tetraethylene glycol ditosylate, (Scheme 3).

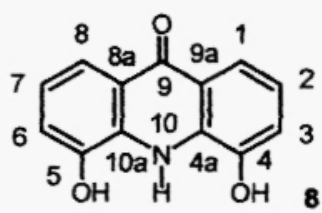

Scheme 3.<smiles></smiles>

As in the case of diamino ligand 5 we performed first the $O$-acylation of acridinone 8 with different acyl halides in DMF with cesium fluoride to obtained monomeric macrocycles. With adipoyl chloride, $(n=4)$, a mixture of oligomeric mono and diacylated acridinones was obtained with 1:1 and 1:2 acridinone/acyl chain ratios. These oligomers were not separable by chromatography; whereas use of pimeloyl, suberoyl or adipoyl chlorides, ( $n=5$ to 7 ), led to only the macrocyclic dilactones 10a-c with 1:1 ratio after purification (Scheme 4). ${ }^{(14)}$

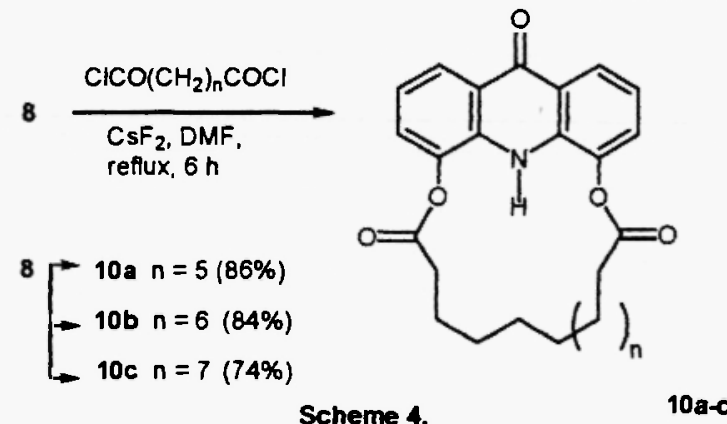

The differentiation and characterization of these macrocycles from by-products was unambiguously supported by the ${ }^{1} \mathrm{H}$ and ${ }^{13} \mathrm{C}$ NMR spectra, in particular by the evaluation of the multiplet pattern of the $\mathrm{C}$-protons signals. For example in the 
case of macrocycle $10 \mathrm{~b}$, two doublets are observed at $\delta 8.14$ and 7.63 for $\mathrm{H}-1$ and $\mathrm{H}-3$ respectively while a triplet appears at $\delta 7.34$ for H-2 (acridinic moiety). Three signals related to the aliphatic protons also prove the unique cyclised structure with a triplet at $2.84 \mathrm{ppm}$ (H-13 protons), and two multiplets at 1.73 and $1.49 \mathrm{ppm}$ corresponding to $\mathrm{H}-14$ and H-15.

We tried also to prepare crown ethers using 8; such compounds are very interesting in their ability to bind metal and organic cations strongly and selectively, ${ }^{(15)}$ and Bradshaw has prepared numerous crown ethers ligands containing pyridines as aromatic moiety and has established a tripod-like hydrogen bounding involving the nitrogen atom and two alternate oxygen atoms in the macrocycle with guest molecule; ${ }^{(16)}$ moreover he recently reported the synthesis of a new ligand based on an acridine subunit whose $\pi$-system provided stonger $\pi$ - $\pi$ interactions with aromatic guests. ${ }^{(17)}$

To obtain the crown ethers 11a and 11b, the acridinone 8 was reacted with ethylene glycol di-p-tosylate using cesium fluoride in DMF. The best results in the isolation of only one macrocyclic monomer were obtained with tetra and penta ethylene glycol ditosylate ${ }^{(18)}$ In this latter case the characterization of $11 \mathrm{a}$ and $11 \mathrm{~b}$ by ${ }^{1} \mathrm{H}$ and ${ }^{13} \mathrm{C}$ NMR spectroscopy, in particular the multiplet patterns in 'H NMR was very similar to those observed for macrocycles 10a-c. (Scheme 5)

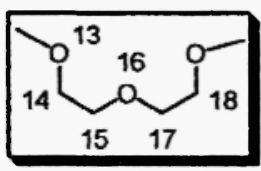

Scheme 5 .

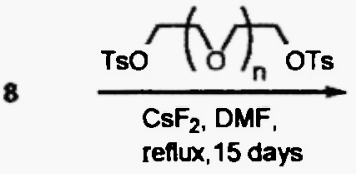

${ }^{8}\left[\begin{array}{r}11 a n=4(26 \%) \\ -11 b n=5(31 \%)\end{array}\right.$

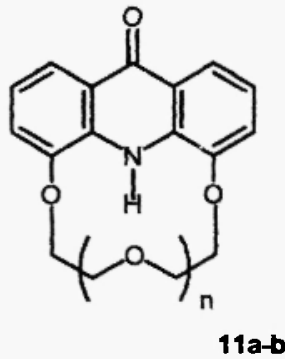

In conclusion, we reported the preparation of a new class of monomeric macrocycles and crown ethers: the 4,5(diamido- $\alpha ", \omega "$-alkyl)acridin- $9(10 H)$-ones and the 4,5-(dihydroxy- $\alpha ", \omega "$-alkyl)acridin- $9(10 H)$-ones; biological testing is now currently in progress to investigate their therapeutical activity.

\section{Notes and References}

1 Baguley, B.C.; Zhuang, L.; Marshall, E.M. Cancer Chemother. Pharmacol. 1995, 36, 244. Johnson, D.S.; Boger D.L. Comprehensive Supramolecular Chemistry; Atwood, J.L., Ed.; Pergamon: Oxford, 1996; vol. 4, ch. 3; Wakelin, L.P.G.; Waring, M.J. Comprehensive Medicinal Chemistry; Sammes, P.G; Taylor, J.B., Ed.; Pergamon: Oxford, 1990 ; vol. 2, ch. 10.1

2 Denny, W. A. Anti-Cancer Drug Des. 1989, 4, 241. Lerman, L.S. J. Mol. Biol. 1961, 3, 18.

3 Issmaili, S.; Boyer, G.; Galy, J.-P. Synlett 1999, 5, 641. Moisan, M. Galy, J.-P.; Galy, A-M; Barbe, J. Monatsh. Chem. 1993, 124, 23. Boyer, G.; Galy J.-P.; Barbe, J. J. Heterocycl. Chem. 1991, 28, 913 . Mannani, R.; Atassi, G.; Galy, A-M; Galy, J.-P.; Barbe, J. Eur. J. Med. Chem. 1991, 26, 117. Vidal, R; Ammor, S.; Galy, A-M; Barbe, J. J. Chem.Eng. Data 1986, 31, 374. Vıdal, R, Galy, J.-P.; Vincent, E.J.V.; Galy, A-M.; Barbe, J. Heterocycles 1986, $24,5,1419$.

4 Filloux, N.; Galy, J.-P. Synlett 2001, 7, 1137.

5 Galy, J.-P.; Galy, A-M; Vichet, A; Elguero, J. Monatsh. Chem. 1998, 129, 1199. Vidal, R.; Galy, J.-P.; Vincent, E.J.V.; Galy, A.-M.; Barbe J. Synthesis 1988, 2, 148. 
6 Djeridi, D.; Galy J.-P.; Barbe J. Synthetic Commun. 1991, 21, 8, 969. Vichet, A.; Patellis, A.M; Galy, J.-P.; Galy, A.-M.; Barbe, J.; Elguero, J. J. Org. Chem. 1994, 59, 5156.

7 Goldberg, AA; Kelly W. J. Chem. Soc. 1947, 515. Klein, E.R Lahey F.N. J. Chem. Soc. 1947, 1418.

8 2-Bromo-3-nitrobenzoïc acid 1 was prepared according to the literature: Culhane P.J., Org. Synth. 1927, 7, 12. Preparation of $3: 2 \mathrm{~g}$ of compound $1,1 \mathrm{~g}$ of 2-nitroaniline 2, $0.051 \mathrm{~g}$ of $\mathrm{Cu}$ powder and $1.66 \mathrm{~g}^{\circ} \mathrm{K}_{2} \mathrm{CO}_{3}$ were heated at $190^{\circ} \mathrm{C}$ for $2 \mathrm{~h}$. Then, after addition of $25 \mathrm{ml}$ of water and active coal, the mixture was refluxed under stirring during $1 \mathrm{~h}$ more. The solution was warned under reflux, filtered and acidified with $36 \% \mathrm{HCl}$, the obtained precipitate was filtered, washed with water and dried. The brown powder was dissolved in $5 \mathrm{ml}$ of $\mathrm{NaOH} \mathrm{lM}$, the alcaline solution was filtered and the $\mathrm{pH}$ was adjusted to 5 with $36 \% \mathrm{HCl}$ The obtained precipitate was filtered, washed with boiling water and dried to yield a yellow powder $3(54 \%)$. Mp $240{ }^{\circ} \mathrm{C}$. Calcd for $\mathrm{C}_{13} \mathrm{H}_{9} \mathrm{~N}_{3} \mathrm{O}_{6}: \mathrm{C}: 51.50, \mathrm{H}: 2.99, \mathrm{~N}$ 103.56. Found: C: $51.72, \mathrm{H}: 3.02, \mathrm{~N}: 103.48 .{ }^{1} \mathrm{H}$ NMR (DMSO-d $\mathrm{d}_{6}$ ): $\delta 6.95\left(1 \mathrm{H}, \mathrm{dd}, \mathrm{J}=1.3,8.1 \mathrm{~Hz}, \mathrm{H}-6^{\prime}\right), 7.07$ $\left(1 \mathrm{H}\right.$, ddd, $\left.\mathrm{J}=1.3,7.1,8.1 \mathrm{~Hz}, \mathrm{H}-4^{\prime}\right), 7.40(1 \mathrm{H}, \mathrm{t}, \mathrm{J}=8.0 \mathrm{~Hz}, \mathrm{H}-5), 7.51\left(1 \mathrm{H}\right.$, ddd, $\left.\mathrm{J}=1.4,7.1,8.2 \mathrm{~Hz}, \mathrm{H}-5^{\prime}\right), 8.12$ $\left(1 \mathrm{H}, \mathrm{dd}, \mathrm{J}=1.6,8.0 \mathrm{~Hz}, \mathrm{H}-3^{\prime}\right), 8.20(1 \mathrm{H}, \mathrm{dd}, \mathrm{J}=1.6,8.0 \mathrm{~Hz}, \mathrm{H}-4), 8.25(1 \mathrm{H}, \mathrm{dd}, \mathrm{J}=1.5,8.1 \mathrm{~Hz}, \mathrm{H}-6), 10.70(1 \mathrm{H}$, s, NH), $14.00(1 \mathrm{H}, \mathrm{s}, \mathrm{COOH}),{ }^{13} \mathrm{C}$ NMR (DMSO-d $)$ ) 8117.31 (C-6'), 121.31 (C-4'), 123.35 (C-5), 125.46 (C-1), 126.16 (C-3'), 130.10 (C-4), 135.12 (C-2), 135.60 (C-5'), 136.56 (C-6), 137.35 (C-2'), 138.84 (C-1'), 142.70 (C$3), 167.36(\mathrm{COOH})$.

9 Preparation of 4: $5 \mathrm{~g}$ of 2',3-dinitrophenylanthranilic acid 3 were added to $50 \mathrm{~g}$ of PPA and heated at $100^{\circ} \mathrm{C}$ for $3 \mathrm{~h}$ Then ice was added to the mixture and stirring maintained until all product dissolved. The solution was precipitated with $1 \mathrm{M} \mathrm{NaOH}(\mathrm{pH}=9-10)$, and the green powder obtained was filtered and dried to yield 4,5-dinitro-9 $(10 H)$ acridinone $4(91 \%)$. Mp $2588^{\circ} \mathrm{C}$. Calcd for $\mathrm{C}_{13} \mathrm{H}_{7} \mathrm{~N}_{3} \mathrm{O}_{5}: \mathrm{C}: 54.75, \mathrm{H}: 2.47, \mathrm{~N}: 14.73$. Found: C: 54.82, $\mathrm{H}: 2.53, \mathrm{~N}$ : 14.84. ${ }^{1} \mathrm{H}$ NMR (DMSO-d $\left.\mathrm{d}_{6}\right) . \delta 7.58(2 \mathrm{H}, \mathrm{t}, \mathrm{J}=8.0 \mathrm{~Hz}, \mathrm{H}-2), 8.69(2 \mathrm{H}, \mathrm{dd}, \mathrm{J}=1.6,8.0 \mathrm{~Hz}, \mathrm{H}-3), 8.85(2 \mathrm{H}, \mathrm{dd}, \mathrm{J}=$ $1.5,7.9 \mathrm{~Hz}, \mathrm{H}-1), 13.44$ (1H, s, NH). ${ }^{13} \mathrm{C}$ NMR (DMSO-d 6 ): $\delta 132.62$ (C-3), 134.99 (C-1), 122.34 (C-2), 123.08 (C-8a), 135.44 (C-4a), $134.68(\mathrm{C}-4), 175.00(\mathrm{CO})$.

10 Preparation of 5: $3 \mathrm{~g}$ of 4,5-dintro-9(10H)-acndinone 4 and $27.4 \mathrm{~g}$ of $\mathrm{SnCl}_{2}$ were added to $40 \mathrm{ml}$ of $36 \% \mathrm{HCl}$ and heated at $100^{\circ} \mathrm{C}$ for $2 \mathrm{~h}$. The mixture was filtered and the precipitate was washed with $\mathrm{HCl} 6 \mathrm{M}(100 \mathrm{ml})$ and dried. This precipitate was dissolved in cold $\mathrm{NaOH} 1 \mathrm{M}(100 \mathrm{ml})$; and the $\mathrm{pH}$ adjusted to 7 with $36 \% \mathrm{HCl}$ The obtained precipitate was filtered, washed with water and dried to yield a green powder of 4,5-diamino-9(10H)-acridinone 5 (78\%). Mp $250{ }^{\circ} \mathrm{C}$. Calcd for $\mathrm{C}_{13} \mathrm{H}_{11} \mathrm{~N}_{3} \mathrm{O}_{2}: \mathrm{C}: 69.33, \mathrm{H}: 4.92, \mathrm{~N}: 18.66$. Found: $\mathrm{C}: 69.45, \mathrm{H}: 4.98, \mathrm{~N}: 18.85 .{ }^{1} \mathrm{H}$ NMR (DMSO-d $\left.)_{6}\right): \delta 5.69\left(4 \mathrm{H}, \mathrm{s}, \mathrm{NH}_{2}\right), 6.99(2 \mathrm{H}, \mathrm{dd}, \mathrm{J}=1.5,8.1 \mathrm{~Hz}, \mathrm{H}-3), 6.99(2 \mathrm{H}, \mathrm{dd}, \mathrm{J}=1.6,7.9 \mathrm{~Hz}, \mathrm{H}-1)$, $7.51(2 \mathrm{H}, \mathrm{t}, \mathrm{J}=7.9 \mathrm{~Hz}, \mathrm{H}-2), 8.72(1 \mathrm{H}, \mathrm{s}, \mathrm{NH}){ }^{13} \mathrm{C}$ NMR (DMSO-d 6 ): $\delta 113.92(\mathrm{C}-3), 116.28(\mathrm{C}-1), 121.31(\mathrm{C}-2)$, $121.72(\mathrm{C}-8 \mathrm{a}), 129.63(\mathrm{C}-4 \mathrm{a}), 137.17(\mathrm{C}-4), 177.61(\mathrm{CO})$

11 General preparation for macrocycles 6 and 7: 4,5-aminoacridinone $5(0.2 \mathrm{~g}, 0.88 \mathrm{mmol})$ was added to refluxed dry pyridine $(150 \mathrm{ml})$. A second solution of acyl dichloride $(2.64 \mathrm{mmol})$ dissolved in DMF $(50 \mathrm{ml})$ was added dropwise to the first solution during $3 \mathrm{~h}$. The red solution was warmed under reflux during 0.5 hour more and filtrated. The solution was concentrated and boiling water $(10 \mathrm{ml})$ was added to the obtained oil. The obtained precipitate was filtered, washed with water and dried to yield a crude mixture of macrocycles 6 and 7 . This mixture was dissolved in $50 \mathrm{ml}$ of $\mathrm{NaOH} 1 \mathrm{M}$, and filtrated to yield an insoluble precipitate and a filtrate. The precipitate was washed with water and dried to yield a beige powder corresponding to the oligomeric 4,5-(diamido- $\alpha ", \omega "$-alkyl)acridin- $9(10 H)$ ones 6. The filtrate was concentrated, dissolved in acetone $(5-10 \mathrm{ml})$ and filtered, then the solution was evaporated yielding a brown powder of diamides 7 .

Spectroscopic data of selected compound $6 \mathrm{c}$ : $\mathrm{Mp} 325^{\circ} \mathrm{C}$. Calcd for $\mathrm{C}_{23} \mathrm{H}_{23} \mathrm{~N}_{3} \mathrm{O}_{3}: \mathrm{C}: 70.57, \mathrm{H}: 6.44, \mathrm{~N}: 10.73$ Found: C: $70.60, \mathrm{H}: 6.48, \mathrm{~N}: 10.62 .{ }^{1} \mathrm{H}-\mathrm{NMR}\left(\mathrm{DMSO}_{-} \mathrm{d}_{6}\right) ; \delta 1.37(8 \mathrm{H}, \mathrm{m}, \mathrm{H}-15$ and $\mathrm{H}-16), 1.70(4 \mathrm{H}, \mathrm{m}, \mathrm{H}-14)$, $2.44(4 \mathrm{H}, \mathrm{n}, \mathrm{H}-13), 7.21(2 \mathrm{H}, \mathrm{t}, \mathrm{J}=7.9 \mathrm{~Hz}, \mathrm{H}-2), 7.67(2 \mathrm{H}, \mathrm{dd}, \mathrm{J}=1.5,7.9 \mathrm{~Hz}, \mathrm{H}-3), 8.11(2 \mathrm{H}, \mathrm{dd}, \mathrm{J}=1.6,7.8 \mathrm{~Hz}$ $\mathrm{H}-1), 10.12(1 \mathrm{H}, \mathrm{s}, \mathrm{NH}) .{ }^{13} \mathrm{C}$ NMR (DMSO-d $\left.\mathrm{d}_{6}\right): \delta 23.85$ (C-16), 26.53 (C-15), 27.74 (C-14), 35.64 (C-13), 121.51 (C-2), 122.17 (C-8a), 124.09 (C-1), 126.24 (C-4), 130.76 (C-3), 135.57 (C-4a), 173.60 (C-12), 174.00 (CO).

Spectroscopic data of selected compound 7c: $\mathrm{Mp} 238{ }^{\circ} \mathrm{C}$. Calcd for $\mathrm{C}_{33} \mathrm{H}_{4:} \mathrm{N}_{3} \mathrm{O}_{7}: \mathrm{C}: 66.76, \mathrm{H}: 6.56, \mathrm{~N}: 7.81$. Found: C: $66.80, \mathrm{H}: 6.62, \mathrm{~N}: 7.65 .{ }^{1} \mathrm{H}-\mathrm{NMR}$ (DMSO-d $\left.\mathrm{d}_{6}\right): \delta 1.28(16 \mathrm{H}, \mathrm{m}, \mathrm{H}-15 \mathrm{and} \mathrm{H}-18), 1.48(4 \mathrm{H}, \mathrm{m}, \mathrm{H}-19), 1.66(4 \mathrm{H}$, $\mathrm{m}, \mathrm{H}-14), 2.14(4 \mathrm{H}, \mathrm{t}, \mathrm{J}=7.1 \mathrm{~Hz}, \mathrm{H}-20), 2.47(4 \mathrm{H}, \mathrm{m}, \mathrm{H}-13), 7.20(2 \mathrm{H}, \mathrm{t}, \mathrm{J}=8.0 \mathrm{~Hz}, \mathrm{H}-2), 7.60(2 \mathrm{H}, \mathrm{dd}, \mathrm{J}=1.6$, $8.0 \mathrm{~Hz}, \mathrm{H}-3), 8.11(2 \mathrm{H}, \mathrm{dd}, \mathrm{J}=1.6,7.9 \mathrm{~Hz}, \mathrm{H}-1), 9.92(1 \mathrm{H}, \mathrm{s}, \mathrm{NH}) .{ }^{13} \mathrm{C}$ NMR (DMSO-d $\left.\mathrm{d}_{6}\right): \delta 27.40$ (C-19), 25.12 (C-14), 28.60 (C-18), 28.70 (C-17), 28.76 (C-16), 28.86 (C-15), 35.74 (C-13), 121.43 (C-2), 121.49 (C-8a), 123.40 
(C-3), 126.64 (C-1), 129.61 (C-4), 135.26 (C-4a), 172.63 (CO), 174.62 (COOH), 176.70 (C-9).

12 Issmaili, S.; Pique, V.; Galy, J.-P; Faure, R Magn. Res. Chem. 1999, 37, 591.

13 Huszthy, P.; Kontos, Z ; Vermes, B.; Pinter, A. Tetrahedron 2001, 57, 4967.

14 General preparation for macrocycles $10 \mathrm{a}-\mathrm{c}: 4,5$-dihydroxyacridinone $8(0.15 \mathrm{~g}, 0.66 \mathrm{mmol})$ was added to refluxed dry DMF $(90 \mathrm{ml})$; then cesium fluoride $(0.3 \mathrm{~g}, 1.97 \mathrm{mmol})$ was added to the solution, (a drop every $10 \mathrm{~s}$ ), and the mixture stirred during $0.5 \mathrm{~h}$. A second solution of alkyl dichloride $(2.8 \mathrm{mmol})$ dissolved in DMF $(50 \mathrm{ml})$ was added dropwise to the first solution during $4 \mathrm{~h}$. The mixture was warmed under reflux during 3 hours and the orange precipitate obtained was filtered and dried. Boiling water $(10 \mathrm{ml})$ was added to the residue and the mixture was filtered and dried. The corresponding macrocycles 10a-c were obtained.

Spectroscopic data of selected compound 10b: $\mathrm{mp} 225^{\circ} \mathrm{C}$. Calcd for $\mathrm{C}_{21} \mathrm{H}_{1} \mathrm{NO}_{5}: \mathrm{C}: 69.03, \mathrm{H}: 5.24, \mathrm{~N}: 3.83$. Found: C: $69.12, \mathrm{H}: 5.15, \mathrm{~N}: 3.68$. 'H-NMR (DMSO-d $): \delta 1.49(4 \mathrm{H}, \mathrm{m}, \mathrm{H}-15), 1.73(4 \mathrm{H}, \mathrm{m}, \mathrm{H}-14), 2.84(4 \mathrm{H}, \mathrm{t}, \mathrm{J}=7.5$ $\mathrm{Hz}, \mathrm{H}-13), 7.34(2 \mathrm{H}, \mathrm{t}, \mathrm{J}=8.1 \mathrm{~Hz}, \mathrm{H}-2), 7.63(2 \mathrm{H}, \mathrm{dd}, \mathrm{J}=1.4,8.1 \mathrm{~Hz}, \mathrm{H}-3), 8.14(2 \mathrm{H}, \mathrm{dd}, \mathrm{J}=1.5,8.1 \mathrm{~Hz}, \mathrm{H}-1)$, $9.54(1 \mathrm{H}, \mathrm{s}, \mathrm{NH}) .{ }^{13} \mathrm{C}$ NMR (DMSO-d $): \delta 23.19$ (C-15), 27.17 (C-14), 32.95 (C-13), $121.86(\mathrm{C}-2), 122.20$ (C-8a), 123.92 (C-3), 127.56 (C-1), 133.95 (C-4a), 139.21 (C-4), 171.94 (CO), 176.23 (C-9).

15 Pedersen, C.J. Synthetic Multidentate Macrocyclic Compounds; Izatt, RM and Christensen, J.J. Eds.; Academic Press: New York, 1978, 21. Izatt, RM.; Pawlak, K.; Bradshaw, J.S.; Bruening, R.L. Chem. Rev. 1991, 91, 1721. Izatt, RM; Pawlak, K; Bradshaw, J.S.; Bruening, RL. Chem. Rev. 1995, 95, 2559.

16 Bradshaw, J.S.; Huszthy, P., McDaniel, C.W.; Zhu, C.-Y.; Dalley, N.K.; Lifson, S. J. Org. Chem. 1990, 55, 3129. Huszthy, P.; Bradshaw, J.S.; Zhu, C.-Y.; Izatt, RM. Lifson, S. J. Org. Chem. 1991, 56, 3330. Huszthy, P.; Oue, M; Bradshaw, J.S.; Zhu, C.-Y.; Wang, T.-M.; Dalley, N.K; Curtis, J.C.; Izatt, RM J. Org. Chem. 1992, 57, 5383. Habata, Y.; Bradshaw, J.S.; Young, J.J.; Castle, S.L.; Huszthy, P.; Pyo, T.; Lee, M.L.; Izatt, RM J. Org. Chem. $1996,61,8391$.

17 Huszthy, P.; Samu, E.; Vermes, B.; Mezey-Vandor, G.; Nogrady, M.; Bradshaw, J. S.; Izatt, RM. Tetrahedron, $1999,55,1491$

18 General preparation for macrocycles $11 \mathrm{a}-\mathrm{b}: 4,5$-dihydroxyacridinone $8(0.2 \mathrm{~g}, 0.88 \mathrm{mmol})$ was added to refluxed dry DMF $(90 \mathrm{ml})$; then cesium fluoride $(0.7 \mathrm{~g}, 4.6 \mathrm{mmol})$ was added and the mixture stirred during $1 \mathrm{~h}$. A second solution of tetra or penta ethylene glycol ditosylate $(1.9 \mathrm{mmol})$ was prepared in DMF $(15 \mathrm{ml})$ and added slowly to the mixture (a drop every 10s). The mixture was stirred during 15 days. The red solution was filtered and evaporated. Acetonitrile $(10 \mathrm{ml})$ was added to the recovered red oil and the solution was warmed under reflux and filtered. The solution was evaporated and the residue was added to acetone. This solution was filtered and concentrated. A solution of ethanol/diethyl ether (1/3) was added to the residue and the obtained yellow precipitate was collected by filtration and chromatographied on silicagel in $\mathrm{CH}_{2} \mathrm{Cl}_{2}$ to yield the final product. The corresponding macrocycles 11a and $11 \mathrm{~b}$ were obtained.

Spectroscopic data of selected compound $11 \mathrm{~b}: \mathrm{mp} 184^{\circ} \mathrm{C}$. Calcd for $\mathrm{C}_{23} \mathrm{H}_{27} \mathrm{NO}_{7}: \mathrm{C}: 65.32, \mathrm{H}: 6.34, \mathrm{~N}: 3.26$. Found: C: 65.19, H: 6.20, N: 3.45. MS (FAB): m/z $430\left(\mathrm{MH}^{\circ}\right)$. ${ }^{1} \mathrm{H}-\mathrm{NMR}$ (DMSO-d $\left.\mathrm{d}_{6}\right): 33.55$ (4H, s, H-20), 3.66 (4H, m, $\mathrm{H}-18), 3.68(4 \mathrm{H}, \mathrm{m}, \mathrm{H}-17), 3.92(4 \mathrm{H}, \mathrm{m}, \mathrm{H}-15), 4.39(4 \mathrm{H}, \mathrm{m}, \mathrm{H}-14), 7.22(2 \mathrm{H}, \mathrm{t}, J=7.9 \mathrm{~Hz}, \mathrm{H}-2), 7.37(2 \mathrm{H}, \mathrm{dd}, J=$ $1.5,8.2 \mathrm{~Hz}, \mathrm{H}-3), 7.79(2 \mathrm{H}, \mathrm{dd}, J=1.6,8.0 \mathrm{~Hz}, \mathrm{H}-1), 9.03(1 \mathrm{H}, \mathrm{s}, \mathrm{NH}) .{ }^{13} \mathrm{C}$ NMR (DMSO-d $): 868.47^{*}(\mathrm{C}-14)$, 68.87* (C-15), $70.13^{\circ}$ (C-17), $70.35^{\circ}$ (C-18), 70.45 (C-20), 113.33 (C-1), 117.41 (C-3), 121.24 (C-8a), 121.33 (C2), 130.67 (C-4a), 146.40 (C-4), 176.47 (CO).

$\because$ may be reversed

\section{Received on January 23, 2003}

